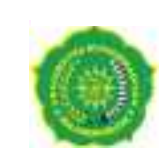

UMP
NERACA

JURNAL PENDIDIKAN EKONOMI

http://journal.umpalangkaraya.ac.id/index.php/neraca

Volume 5 Nomor 2, Mei 2020 (1-13)

\title{
PENGARUH MEKANISME CORPORATE GOVERNANCE, AUDIT TENURE,UKURAN PERUSAHAAN DAN LEVERAGE TERHADAP INTEGRITAS LAPORAN KEUANGAN (STUDI EMPIRIS PADA PERUSAHAAN BUMN YANG TERDAFTAR DI BURSA EFEK INDONESIA) The Effect of Corporate Governance Mechanisms, Audit Tenure, Company Size and Leverage on the Integrity of Financial Statements (Empirical Study of BUMN Companies Listed on Bursa Efek Indonesia) \\ ISiti Fatimah, 2 Ni Putu Agustinawati dan ${ }^{3}$ San Petro \\ 'STIE YBPK Palangka Raya, Palangka Raya, Kalimantan Tengah, Indonesia \\ ${ }^{2}$ STIE YBPK Palangka Raya, Palangka Raya, Kalimantan Tengah, Indonesia \\ ${ }^{3}$ STIE YBPK, Palangka Raya, Palangka Raya, Kalimantan Tengah, Indonesia
}

\section{ARTIKEL INFO}

Diterima

April 2020

Dipublikasi

Mei 2020

*e-mail :

${ }^{1}$ nenksifa7@gmail.com,

np.agustinawati@gmail.com dan

3odedingo@gmail.com

\section{ABSTRAK}

Di Indonesia kasus manipulasi laporan keuangan juga dilakukan oleh perusahaan Badan Usaha Milik Negara (BUMN) yaitu PT Kimia Farma yang terdeteksi adanya manipulasi.Adanya fenomena yang terjadi dapat membuktikan bahwa kurangnya integritas laporan keuangan dalam penyajian informasi bagi pengguna laporan keuangan.Dengan demikian, laporan keuangan dituntut untuk disajikan dengan integritas tinggi. Integritas laporan keuangan tidak lepas dari adanya faktor-faktor yang mempengaruhinya. Tujuan Penelitian untuk menganalisis secara empiris corporate governance, audit tenure, ukuran perusahaan dan leverage terhadap integritas laporan keuangan baik secara parsial maupun simultan. Data dalam penelitian ini merupakan data sekunder dari laporan keuangan tahunan dari 20 perusahaan BUMNyang terdaftar di Bursa Efek Indonesia (BEI) selama periode2013-2017 dengan menggunakan judgment sampling, Analisis data menggunakan SPSS, Secara parsial Kepemilikan Manajerial, Audit Tenure, Ukuran Perusahaan, Leverage berpengaruh positif terhadap integritas laporan keuangan. Sedangkan Kepemilikan Institusional, Komite Audit, Komisaris Independen tidak berpengaruh terhadap integritas laporan keuangan. Bagi penelitian selanjutnya dapat menambah variabel seperti faktor-faktor lain yang tidak termasuk dalam analisis regresi ini, seperti independensi auditor, kualitas audit dan spesialisasi indutri auditor.

Kata kunci: corporate governance, audit tenure, ukuran perusahaan, leverage, integritas laporan keuangan.

\section{ABSTRACT}

In Indonesia the case of manipulation of financial statements was also carried out by a State-Owned Enterprise (BUMN) company, namely PT Kimia Farma, which detected manipulation. The existence of a phenomenon that occurs can prove that the lack of integrity of financial statements in the presentation of information for users of financial statements. Thus, financial statements are required to be presented with high integrity. The integrity of financial statements cannot be separated from the factors that influence it. The purpose of this research is to empirically analyze corporate governance, audit tenure, company size and leverage on the integrity of financial statements both partially and simultaneously. The data in this study are secondary data from the annual financial statements of 20 BUMN companies listed on the Indonesia Stock Exchange (IDX) during the 2013-2017 period using judgment sampling, data analysis using SPSS, Partially Managerial Ownership, Audit Tenure, Company Size, Leverage has a positive effect on the integrity of financial statements. While Institutional Ownership, Audit Committees, Independent Commissioners have no effect on the integrity of financial statements. For further research can add variables such as other factors not included in this regression analysis, such as auditor independence, audit quality and auditor industry specialization.

Keywords: corporate governance, audit tenure, company size, leverage, integrity of financial statements. 


\section{PENDAHULUAN}

Di Indonesia kasus manipulasi laporan keuangan juga dilakukan oleh perusahaan Badan Usaha Milik Negara (BUMN) yaitu PT Kimia Farma yang terdeteksi adanya manipulasi.Berdasarkan temuan audit dari KAP Hans Tuanakotta \& Mustofa, PT. Kimia Farma melakukan kesalahan pencatatan dengan melakukan penggelembungan laba, nilai yang tercatat $R p$ I32 miliar (seharusnya Rp 99 miliar) pada laporan keuangan tahun 200I(Tempo.co, diakses 20 Desember 2019). Akan tetapi, Kementrian BUMN dan BAPEPAM menilai bahwa laba bersih tersebut terlalu besar dan mengandung unsur rekayasa (Kompasiana.com, diakses 20 Desember 2019).

Adanya fenomena yang terjadi dapat membuktikan bahwa kurangnya integritas laporan keuangan dalam penyajian informasi bagi pengguna laporan keuangan. Penyajian laporan tidak melaporkan kondisi perusahaan yang sebenarnya. Jadi, apabila seorang auditor mengaudit laporan keuangan yang tidak berintegritas maka, peluang seorang auditor untuk dituntut akan semakin besar. Apabila laporan keuangan itu oversite akan sangat merugikan bagi pengguna laporan keuangan tersebut(Solikhah et al., 2017).

Setiap perusahaan menyajikan laporan keuangan sebagai bentuk pertanggungjawaban kepada pihak-pihak yang berkepentingan sebagai bentuk tanggung jawab manajemen (Asyati et al., 2020). Sesuai dengan Standar Akuntansi Keuangan (IAI, 20I5) tujuan laporan keuangan adalah menyediakan informasi yang menyangkut posisi keuangan, kinerja, serta perubahan posisi keuangan suatu entitas yang bermanfaat bagi sejumlah besar pengguna dalam pengambilan keputusan ekonomi. Informasi yang dilaporkan seharusnya disajikan secara benar, jujur dan mengungkapkan fakta yang sebenarnya.

Mulyadi (2002) menyatakan integritas merupakan suatu prinsip moral yang tidak berpihak, mengutamakan kejujuran, orang yang memiliki integritas tinggi akan melihat fakta seperti apa adanya dan memberikan fakta yang sebenarnya.Dengan demikian, laporan keuangan dituntut untuk disajikan dengan integritas tinggi. Namun, pada kenyataannya banyak terjadi kasus-kasus hukum yang melibatkan manipulasi data akuntansi khususnya pada laporan keuangan.

Kasus seperti ini melibatkan banyak pihak dan berdampak cukup luas. Keterlibatan CEO, komisaris, komite audit, auditor internal sampai pada auditor eksternal. Hal ini menurunkan tingkat kepercayaan masyarakat terhadap kinerja perusahaan ditandai dengan turunnya harga saham perusahaan. Munculnya kasus ini menimbulkan pernyataan apakah tata kelola perusahaan (corporate governance) tidak diterapkan dengan baik. Di Indonesia sendiri, perbincangan mengenai corporate governance masih menjadi isu yang hangat.

Jensen dan Meckling (1976) dalam Kholmi, 20lOmengatakan bahwa dua macam bentuk hubungan keagenan, yaitu antara manajer dan pemegang saham (shareholders), manajer dan pemberi pinjaman (bondholder).Corporate Governance dalam teori agensi memberikan pandangan terkait manajemen laba, dan dapat diminimalisir melalui mekanisme monitoring yang bersifat alignment antara kepentingan pemilik dan manajemen, kepemilikan saham institusional ini dianggap sophisticated investorkarena kepemilikan yang cukup signifikan (Kusumawatil et al., 20I5). Semakin baik penerapan Corporate Governance yang dilakukan perusahaan (mekanisme pengawasan) maka akan diharapkan dapat mengurangi perilaku manajemen perusahaan yang bersifat oportunistik (Budiasih et al., 2017), sehingga laporan keuangan dapat disajikan dengan integritas yang tinggi, yaitu laporan yang disajikan menunjukan informasi yang benar dan jujur. 
Faktor berikutnya yang berpengaruh terhadap integritas laporan keuangan adalah audit tenure. Audit tenure adalah lamanya jangka waktu KAP atau seorang auditor mengaudit perusahaan (klien) dalam suatu kontrak (Praptikaet al, 2016). Independensi dari auditor akan menurun apabila auditor mendapat tekanan klien dan memiliki hubungan yang dekat dengan klienyang dapat mempengaruhi sikap dan mental mereka dalam memberikan opini(Dewi et al., 2015). Maka, jika suatu perusahaan di audit oleh suatu kantor akuntan publik selama beberapa periode maka akan mempengaruhi objektivitas laporan keuangan. Oleh sebab itu, pemerintah telah mengatur dengan jelas jangka waktu perikatan audit yang tertuang dalam Keputusan Menteri Keuangan Nomor I7/PMK.0I tahun 2008 tentang Jasa Akuntan Publik pasal 3 yaitu pemberian jasa audit umum atas laporan keuangan suatu entitas dapat dilakukan oleh KAP paling lama 6 tahun buku berturut-turut dan seorang akuntan publik paling lama 3 tahun buku berturutturut.Namun ada pandangan lain berhubungan dengan tenure yang lama. Menurut Giri (2010) tenur yang lama akan memberikan keuntungan bagi seorang auditor dalam mendapatkan pengetahuan bisnis klien. Pengetahuan ini dapat digunakan untuk merancang program audit yang efektif dan menciptakan laporan keuangan yang berkualitas tinggi.

Faktor lain yang mempengaruhi integritas laporan keuangan yaitu ukuran perusahaan. Ukuran perusahaan sebagai suatu skala besar kecilnya suatu perusahaan terbagi dalam 3 kategori yaitu perusahaan besar (largefirm), perusahaan menengah (mediumfirm), perusahaan kecil (smallfirm) (Suwito et al, 2005). Dalam Penelitian Riyanto, (1997) ukuran perusahaan dapat dilihat dari total aset, penjualan, dan rata-rata penjualan (Rifai et al., 2015). Ketiga pengukuran tersebut sering digunakan untuk mengidentifikasi besar kecilnya suatu perusahaan karena semakin besar aset yang dimiliki oleh perusahaan, maka semakin besar modal yang ditanam. Semakin besar penjualan, maka semakin besar pula perputaran uang dalam perusahaan tersebut dan semakin besar kapitalisasi pasar maka perusahaan tersebut semakin terkenal oleh masyarakat.

Faktor lain yang juga mempengaruhi integritas laporan keuangan yaitu leverage merupakan jumlah utang yang digunakan untuk membiayai atau membeli aset-aset perusahaan. Perusahaan yang memiliki utang lebih besar dari modal dikatakan sebagai perusahaan dengan tingkat leverage yang tinggi (Fakhruddin, 20I5). Keberadaan tingkat utang dalam struktur pendanaan perusahaan akan meningkatkan pengawasan tidak hanya oleh investor namun juga kreditur(Fajaryani, 2015).Semakin tinggi leverage maka menggambarkan semakin besarnya kewajiban perusahaan terhadap para kreditur.

Tujuan Penelitian untuk menganalisis secara empiris corporate governance, audit tenure, ukuran perusahaan dan leverageterhadap integritas laporan keuangan. Penelitian ini merupakan pengembangan dari penelitian Fajaryani (2015) tentang Analisis Faktor-Faktoryang Mempengaruhi IntegritasLaporan Keuangan. Penelitian ini mempunyai persamaan pada variabel kepemilikan institusional, manajerial, dan ukuran perusahaan dimana sebagai variabel independen dan Integritas Laporan Keuangan sebagai variabel dependen. Sampel perusahaan yang tercatat di BEI.

Penelitian ini mempunyai perbedaan yakni tidak memasukan variabel independen yaitu spesialisasi industri auditor, perbedaan sampel penelitian terdahulu menggunakan perusahaan pertambangan, sedangkan penelitian ini menggunakan sampel perusahaan perusahaan BUMN (perusahaan plat merah)yang terdaftar di BEI.Penambahan variabel independen yaitu audit tenure, ukuran 
perusahaan dan leverage. Sehingga pada penelitian ini variabel yang digunakan yaitu mekanisme corporate governance, audit tenure, ukuran perusahaan dan leverage.

Pemilihan sampel ini dipilih karena BUMN adalah salah satu pilar ekonomi, karena beberapa BUMN berada dalam industri vital dan strategis sehingga peningkatan kinerja BUMN harus memberikan implikasi positif terhadap perekonomian Indonesia (Setiawan, 2016). Tahun pengamatan objek penelitian ini lima tahun dimulai tahun 2013 hingga 2017.

Hipotesis

$\mathrm{H}_{1}$ :Proporsi kepemilikan institusional berpengaruh positif terhadap integritas laporan keuangan.

$\mathrm{H}_{2}$ : Proporsi kepemilikan manajerial berpengaruh negatif terhadap integritas laporan keuangan.

H3: Jumlah komite audit berpengaruh negatif terhadap integritas laporan keuangan.

$\mathrm{H}_{4}$ :Proporsi komisaris independen berpengaruh negatifterhadap integritas laporan keuangan.

H5: Audit tenure berpengaruh positif terhadap integritas laporan keuangan.

H6: Ukuran perusahaan berpengaruh positif terhadap integritas laporan keuangan.

H7: Leverage berpengaruh positif terhadap integritas laporan keuangan.

H8: Kepemilikan institusional, kepemilikan manajerial, komite audit, komisaris independen, audit tenure, ukuran perusahaan dan leverage secara simultan berpengaruh terhadap integritas laporan keuangan.

\section{METODOLOGI PENELITIAN}

Data dalam penelitian ini merupakan data sekunder dari laporan keuangan tahunan dari 20 perusahaan BUMNyang terdaftar di Bursa Efek Indonesia (BEI) periode 20I3-20I7 dengan menggunakan judgment sampling. Teknik pengumpulan data melalui studi literatur dan dokumentasi. Metode Analisis data dengan statistik deskriptif, uji asumsi klasik (yang terdiri dari uji normalitas, multikolinieritas, autokorelasi, dan Heteroskedastisitas), uji hipotesis (regresi berganda, uji statistik t, uji statistik $f$, uji koefisien determinasi) danAnalisis data menggunakan SPSS Ver.23.

\section{Definisi Operasional Variabel}

\section{a. Integritas Laporan Keuangan}

Indeks konservatisme sebagai proksi Integritas laporan keuangan dihitung dengan model Beaver yang digunakan juga oleh Fajaryani (2015) menggunakan market to book ratio, yaitu (Fajaryani, 2015):

$$
\mathrm{ILK}_{\mathrm{i1}}=\frac{\text { Harga Pasar saham }}{\text { Nilai Buku Saham }}
$$

Keterangan:

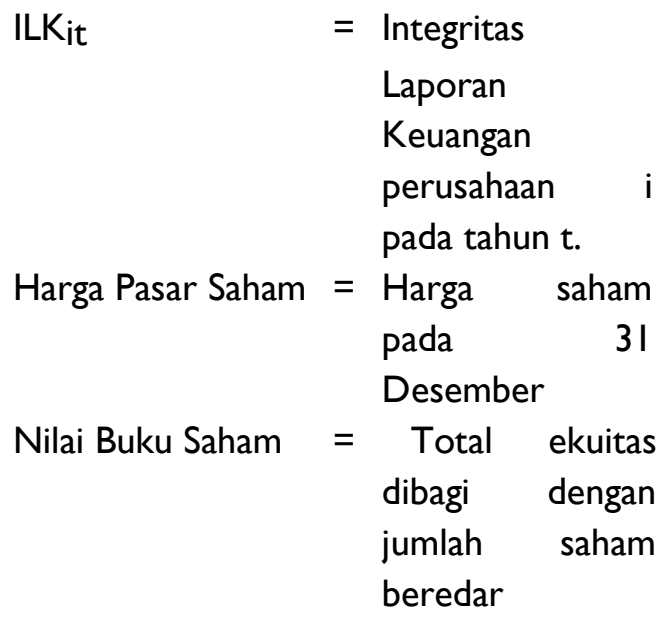

b. Kepemillikan Institusional

Jumlah saham yang dimiliki oleh pihak eksternal, seperti bank, perusahaan asuransi dan institusi lainnya (Saveroet al., 2017). Yaitu:

INS

$=\frac{\text { Jumlah Saham yang dimiliki institusional }}{\text { Jumlah Saham Beredar }}$ 
c. Kepemilikan Manajerial

Suatu proporsi saham yang dimiliki manajemen yang secara aktif turutdalampengambilan keputusan perusahaan, meliputi dewan direksi dan dewan komisaris (Fajaryani, 2015). Yaitu: MAN

$=\frac{\text { Jumlah Saham yang dimiliki Manajemen }}{\text { Jumlah Saham Beredar }}$

d. Komite Audit

Komite Audir berperan penting dalam fungsi pengawasan dan memonitor audit laporan keuangan, terpenuhinya kepatuhan perusahaan terhadap standar dan kebijakan keuangan, menelaah hasil audit internal dan eksternal, dan melaporkan ke dewan komisaris(Indrasariet al., 2016). Yaitu: Komite Audit $=$ Jumlah Anggota Komite Audit Perusahaan

e. Komisaris Independen

Keberadaan komisaris independen dapat mempengaruhi integritas suatu laporan keuangan yang dihasilkan oleh manajemen, karena adanya badan pengawasan secara langsung dan melindungi hak-hak pihak minoritas diluar manajemen perusahaan (Hardiningsih, 2010 dalam Indrasari, Yuliandhari et al., 2016)

DKInd

$$
=\frac{\text { Jumlah Komisaris Independen }}{\text { Jumlah Komisaris }}
$$

\section{f. Audit tenure}

Masa perikatan yang dilakukan oleh KAP dengan perusahaan, semakin lama masa penugasan audit, maka semakin tinggi tingkat kualitas audit disebabkan biaya audit yang tinggi dan dilakukan pada klien yang sama (Wibowo dan Roessita, 2009 dalam Herianti et al., 2016). Audit tenure diukur dengan variavel dummy yaitu dengan tenure lama (3 tahun atau lebih) diberi angka I dan tenur singkat (kurang dari 3 tahun)diberi angka0

g. Ukuran Perusahaan

Besar kecilnya perusahaan dapat dilihat dari total aset. Ukuran perusahaan dapat dilihat dari perhitungan logaritma natural dari total aset (Herianti et al., 20l6). Logaritma natural dari total aset perusahaan (Ln Assets) dapat menunjukkan bahwa semakin besar ukuran atau aset suatu perusahaan berarti semakin besar juga angka logaritmanya.

h. Leverage

Pemanfaatan aset dan sumber dana perusahaan yang mempunyai biaya tetap dalam rangka meningkatkan keuntungan potensial pemegang saham (Amperaningrum et al., 20I3).

$$
L=\frac{k_{i}}{t_{1} a}
$$

\section{HASIL DAN PEMBAHASAN}

Berdasarkan metode judgement sampling diperoleh sampel 19 perusahaan dari 20 perusahaan yang memenuhi kriteria sampel yang diterapkan

\section{Tabel I}

\section{Proses Seleksi Sampel}

BerdasarkanKriteria

\begin{tabular}{|c|l|c|}
\hline No & \multicolumn{1}{|c|}{ Kriteria } & Jumlah \\
\hline I & $\begin{array}{l}\text { Total perusahaan BUMN yang terdaftar di } \\
\text { Bursa Efek } \\
\text { Indonesia (BEI) }\end{array}$ & 20 \\
\hline 2 & $\begin{array}{l}\text { Perusahaan yang baru listing selama } \\
\text { Periode penelitian }\end{array}$ & 0 \\
\hline 3 & $\begin{array}{l}\text { Perusahaan tidak menggunakan mata uang } \\
\text { rupiah }\end{array}$ & 19 \\
\hline Data tersedia & 95 \\
\hline \multicolumn{2}{|c|}{ Total sampel selama 5 tahun periodepenelitian } \\
\hline
\end{tabular}


Jurnal Pendidikan Ekonomi

Analisis Statistik Deskriptif. Dibawah ini disajikan hasil setiap variabel operasional:

Tabel 2

Hasil Uji StatistikDeskriptif

Descriptive Statistics

\begin{tabular}{|l|c|r|r|r|r|}
\hline & $\mathrm{N}$ & \multicolumn{1}{c|}{ Min } & \multicolumn{1}{c|}{ Max } & \multicolumn{1}{c|}{ Mean } & Std. Dev. \\
\hline Institusional & 95 & -.78 & .23 & .1404 & .16007 \\
\hline Manajerial & \multicolumn{1}{c|}{95} & .23 & .30 & .2594 & $.0195 \mathrm{I}$ \\
\hline Komite Audit & 95 & 2.00 & 8.00 & 4.0842 & 1.25192 \\
\hline Komisaris Indepen & 95 & .17 & .71 & .3979 & .12393 \\
\hline Audit Tenure & 95 & .00 & 1.00 & .5368 & .50129 \\
\hline Uk. Perusahaan & 95 & .13 & .19 & .1722 & .00847 \\
\hline Leverage & 95 & .07 & .92 & 2.3223 & 11.82262 \\
\hline ILK & 95 & .00 & 7.00 & 2.2316 & 1.49789 \\
\hline Valid N (listwise) & 95 & & & & \\
\hline
\end{tabular}

Sumber: Data sekunder yang diolah

Tabel 4.3 diatas menunjukkan bahwa jumlah data (Valid $N$ ) yang digunakan dalam penelitian ini adalah 95 sampel yang berasal dari laporan keuangan yang dipublikasi oleh perusahaan Badan Usaha Milik Negara (BUMN) yang telah tercatat di Bursa Efek Indonesia (BEI) selama tahun 2013-2017. Berdasarkan hasil tersebut maka semua data pada sampel dapat diolah.

Variabel dependen pada penelitian ini adalah integritas laporan keuangan (ILK). Hasil analisis menggunakan statistik deskriptif terhadap integritas laporan keuangan (ILK) menunjukkan nilai minimum 0 dan nilai maksimum sebesar 7 dengan rata-rata 2,2316. Nilai maksimum pada Perusahaan KAEF (20I6), PTPP (20I4), ini mengindikasikan penerapan akuntansi yang konservatif karena perusahaan mencatat nilai buku saham lebih rendah dari harga pasar saham. Nilai minimum pada Perusahaan ANTM (20I5), PTBA (20I7) SMBR (2013, 2014, 20I5).

Variabel independen yang pertama pada penelitian ini adalah kepemilikan saham institusional (INT), perhitungan INT dengan cara membagi jumlah saham yang dimiliki oleh institusi dengan jumlah saham yang beredar. Hasil analisis dengan menggunakan statistik deskriptif terhadap kepemilikan intstitusional (INT) menunjukkan nilai minimum sebesar $-0,78$ (sebesar I,47\%) dan nilai maksimum sebesar 0,23 (sebesar 49,91\%) dan rata-rata 0, 1404 (sebesar 23\%). Kepemilikan institusional paling kecil pada BBNI (2017).Nilai maksimum palingbesar padaWTON (2013-20I7) dan ADHI, PTPP, SMGR.

Variabel independen yang kedua pada penelitian ini adalah kepemilikan saham manajerial (MAN), perhitungan MAN dengan cara membagi jumlah saham yang dimiliki oleh manajerial dengan jumlah saham beredar. Hasil analisis dengan menggunakan statistic deskriptif terhadap kepemilikan manajerial (MAN) menunjukkan nilai minimum sebesar 0,23 (sebesar 50,09\%) dan nilai maksimum 0,30 (sebesar 98,53\%) dengan rata-rata 0,2594 (sebesar $65 \%$ ). Nilai minimum pada kepemilikan manajerial pada WTON (20I3-20I7),ADHI, PTPP, SMGR, sedangkan nilai maksimum pada BBNI (20132017).

Variabel indepeden yang ketiga pada penelitian ini adalah jumlah komite audit (KAUD), perhitungan KAUD dengan cara menjumlah komite audit pada perusahaan. Hasil analisis menggunakan statistik deskriptif terhadap komite audit (KAUD) menunjukkan nilai minimum sebesar 2 (Sebanyak 2 Orang) dan nilai maksimum sebesar 8 (sebanyak 8 orang) sedangkan nilai rata-rata 4,0842 (sebanyak 4 orang). Nilai minimum pada komite audit pada ADHI (20I4-20I7), sedangkan nilai maksimum pada BBRI (20I3).

Variabel independen yang keempat pada penelitian ini adalah komisaris independen (KIND), perhitungan KIND dengan membagi jumlah komisaris indepeden dengan jumlah komisaris pada suatu perusahaan. Hasil analisis menggunakan statistic deskriptif terhadap komisaris independen (KIND) menunjukkan hasil nilai minimum sebesar 0,17 (sebesar 17\% dari jumlah keseluruhan komisaris independen) 


\section{Jurnal Pendidikan Ekonomi}

dan nilai maksimum sebesar 0,7I (sebesar 71\%) sedangkan nilai rata-rata 0,3979 (sebesar 40\%). Nilai minimum pada komisaris independen pada PTBA (20I5-20I7), sedangkan nilai maksimum pada BBRI (20I4).

Variabel independen yang kelima pada penelitian ini adalah audit tenure (ATEN),pengukuranATEN dengan variable dummy. Pengukuran dengan member angka I pada panjang masa perikatan audit sama atau lebih dari 3 tahun dan angka 0 pada panjang masa perikatan audit singkat yaitu kurang dari 3 tahun. Hasil analisis menggunakan statistic deskriptif terhadap audit tenure (ATEN) menunjukkan hasil nilai minimum 0 dan nilai maksimum sebesar I dengan nilai rata-rata 0,5368 . Untuk variable audit tenure menggunakan variable dummy, oleh karena itu hasil penelitian hanya muncul angka 0 dan I.

Variabel independen yang keenam pada penelitian ini adalah ukuran perusahaan (SIZE), pengukuran SIZE dengan Log total asset. Hasil analisis menggunakan statistic deskriptif terhadap ukuran perusahaan (SIZE) menunjukkan nilai minimum sebesar 0,13 dan nilai maksimum sebesar 0,19 sedangkan nilai rata-rata 0,1722 . Nilai minimum pada perusahaan SMGR (2017) dengan total aset Rp. 48.963.502.966.000, sedangkan nilai maksimum pada perusahaan BBNI (20132017) dengan total asset Rp. 386.654.815.000.000 s/d Rp. 709.330.084.000.000 dan BMRI (20I3-20I7) dengan total aset Rp. 733.099.762.000.000 s/d Rp. I.I24.700.847.000.000.

Variabel independen yang ketujuh pada penelitian ini adalah leverage, pengukuran leverage yaitu dengan membagi Total kewajiban (Hutang jangka pendek + Hutang Jangka Panjang) dengan total aset. Hasil analisis menggunakan statistik deskriptif terhadap leverage menunjukkan nilai minimum sebesar 0,07 (sebesar 7\%) dan nilai maksimum sebesar 0,92 (sebesar 92\%) sedangkan nilai rata-rata 2,3223 (sebesar 23\%). Nilai minimum pada perusahaan SMBR(20I4), hal ini menunjukan bahwa SMBR hanya mempunyai hutang sebesar $7 \%$ dibanding total aset. Nilai maksimum pada perusahaan BBTN (20I4-20I5), hal ini menunjukan bahwa BBTN mempunyai hutang sebesar $92 \%$ dibanding total aset.

Asumsi Klasik. Dari hasil uji normalitas, multikolinieritas, autokorelasi, dan Heteroskedastisitas, semua data memenuhi uji asumsi klasik.

Regresi Berganda. Dibawah ini disajikan persamaan regresi dari tabel:

Tabel 3

Analisis Regresi Berganda

\begin{tabular}{|c|c|c|c|c|}
\hline Variabel & $\begin{array}{c}\text { Koefisien } \\
\text { Regresi }\end{array}$ & $\alpha$ & Sig. & Keterangan \\
\hline Konstanta & 0,135 & 0,05 & 0,866 & Tidak Signifikan \\
\hline Instutisional & $0,3 / 3$ & 0,05 & 0,282 & Tidak Signifikan \\
\hline Manajerial & 5,214 & 0,05 & 0,005 & Signifikan \\
\hline Komite Audit & $-0,018$ & 0,05 & 0,392 & Tidak Signifikan \\
\hline $\begin{array}{l}\text { Komisaris } \\
\text { Independen }\end{array}$ & $0,3 / 3$ & 0,05 & $0,|4|$ & Tidak Signifikan \\
\hline Audit Tenure & 0,168 & 0,05 & 0,001 & Signifikan \\
\hline $\begin{array}{l}\text { Ukuran } \\
\text { Perusahaan }\end{array}$ & 8,062 & 0,05 & 0,006 & Signifikan \\
\hline Leverage & 0,001 & 0,05 & 0,031 & Signifikan \\
\hline \multicolumn{5}{|c|}{ R Square $(r 2)=0,470$} \\
\hline \multicolumn{5}{|c|}{ Adj.R Square $=0,450$} \\
\hline \multicolumn{5}{|c|}{ Fhitung $=3,940$} \\
\hline \multicolumn{5}{|l|}{ Sig.f $=0,048$} \\
\hline Variabel Terka & & & & \\
\hline
\end{tabular}

Sumber: Data sekunderyangdiolah

Berdasarkan tabel 3, maka diperoleh persamaan regresi sebagai berikut:

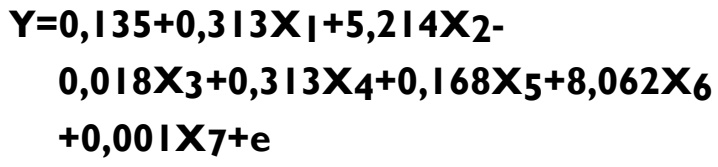


Uji Signifikansi Parameter Individual (Uji Statistik t). Hasil pengujian uji signifikansi parameter individual (ujistatistikt):

Tabel 4

Hasil Uji Signifikansi Parameter Individual (Uji Statistik t)

\begin{tabular}{|c|c|c|c|c|c|}
\hline \multicolumn{6}{|c|}{ Coefficients $^{a}$} \\
\hline & \multirow{2}{*}{ Model } & \multicolumn{2}{|c|}{$\begin{array}{l}\text { Unstandardized } \\
\text { Coefficients }\end{array}$} & \multirow{2}{*}{$\begin{array}{c}\text { Standardized } \\
\text { Coefficients } \\
\text { Beta }\end{array}$} & \multirow[b]{2}{*}{$\mathrm{t}$} \\
\hline & & B & $\begin{array}{l}\text { Std. } \\
\text { Error }\end{array}$ & & \\
\hline \multirow[t]{8}{*}{ I } & (Constant) & .135 & .796 & & .169 \\
\hline & Institusional & .313 & .289 & .203 & 1.083 \\
\hline & Manajerial & 5.214 & 1.818 & .413 & 2.869 \\
\hline & Komite Audit & -.018 & .021 & -.091 & -.860 \\
\hline & $\begin{array}{l}\text { Komisaris } \\
\text { Indepen }\end{array}$ & .313 & .211 & .157 & 1.485 \\
\hline & Audit Tenure & .168 & .047 & $.34 I$ & 3.548 \\
\hline & Uk. Perusahaan & 8.062 & 2.874 & -.277 & -2.805 \\
\hline & Leverage & .001 & .003 & -.052 & -.412 \\
\hline
\end{tabular}

Sumber: Data sekunderyangdiolah

Hasil uji dari tabel 4 di atas menunjukan hasil parsial sebagai berikut:

I) Kepemilikan Institusional tidak berpengaruh terhadap Integritas Laporan Keuangan yang dibuktikan dengan nilai thitung sebesar I,083 lebih kecil dari ttabel yaitu I,662 $(I, 083<1,662)$ dan nilai probabilitas signifikansi sebesar 0,282 yang lebih besar dari tingkat signifikansi yang ditentukan, yaitu 0,05 $(0,282>0,05)$.

2) Kepemilikan Manajerial berpengaruh terhadap Integritas Laporan Keuangan yang dibuktikan dengan nilai thitung sebesar 2,869 lebih besar dari ttabel yaitu I,662 (2,869>1,662) dan nilai probabilitas signifikansi sebesar 0,005 yang lebih kecil dari tingkat signifikansi yang ditentukan, $0,05(0,005<0,05)$.

3) Komite audit tidak berpengaruh terhadap Integritas Laporan Keuangan yang dibuktikan dengan nilai thitung sebesar 0,860 lebih kecil dari ttabel yaitu I,662 ($0,860<1,662)$ dan nilai probabilitas signifikansi sebesar 0,392 lebih besar dari tingkat signifikansi yang ditentukan, , 0,05 $(0,392>0,05)$.
4) Komisaris Independen tidak berpengaruh terhadap Integritas Laporan Keuangan yang dibuktikan dengan nilai thitung sebesar 1,485 lebih kecil dari ttabel yaitu I,662 $(1,485<1,662)$ dan nilai probabilitas signifikansi sebesar 0, I4I lebih besar dari tingkat signifikansi yang ditentukan, , 0,05 $(0,|4|>0,05)$.

5) Audit Tenure berpengaruh terhadap Integritas Laporan Keuangan yang .86 dibuktikan dengan nilai thitung sebesar .283,548 lebih besar dari ttabel yaitu I,662 $.0053,548>1,662$ ) dan nilai probabilitas .14 signifikansi sebesar 0,001 yang lebih kecil dari tingkat signifikansi yang ditentukan, $000,05(0,001<0,05)$.

6).03 kuran Perusahaan berpengaruh terhadap Integritas Laporan Keuangan yang dibuktikan dengan nilai thitung sebesar -2,805 lebih kecil dari ttabel yaitu I,662 $(-2,805<1,662) \quad$ dan nilai probabilitas signifikansi sebesar 0,006 yang lebih kecil dari tingkat signifikansi yang ditentukan, $0,05(0,006<0,05)$.

Leverage berpengaruh terhadap Integritas Laporan Keuangan yang dibuktikan dengan nilai thitung sebesar $-0,412$ lebih kecil dari ttabel yaitu $1,662(-0,412<1,662)$ dan nilai probabilitas signifikansi sebesar 0,031 yang lebih kecil dari tingkat signifikansi yang ditentukan, 0,05 $(0,03 \mid<0,05)$.

\section{Uji Signifikansi Simultan (Uji Statistik}

F). Berikut ini adalah hasil uji statistik:

\section{Tabel 5}

\section{Hasil Uji Signifikansi Simultan (Uji} StatisitikF) ANOVAa

\begin{tabular}{|c|l|r|r|r|r|r|}
\hline \multicolumn{2}{|c|}{ Model } & Sum of Squares & df & Square & F & Sig. \\
\hline \multirow{2}{*}{$\mathrm{I}$} & Regression & 1,002 & 7 &, 143 & 3,940 & $0,048^{\mathrm{b}}$ \\
\cline { 2 - 8 } & Residual & 13,246 & 87 &, 152 & & \\
\cline { 2 - 7 } & Total & 14,248 & 94 & & & \\
\hline
\end{tabular}

Sumber: Data sekunderyangdiolah

Tabel 5 diatas menunjukan bahwa dapat diketahui variabel independen secara 
Jurnal Pendidikan Ekonomi

bersama-sama berpengaruh terhadap variabel dependen. Hal ini dibuktikan dengan nilai $F_{\text {hitung }} 3,940$ yang lebih besar dari pada $F_{\text {tabel }}$ yaitu 2, I $2(3,930>2,12$ dan nilai probabbilitas signifikansi sebesar 0,048 yang lebih kecil dari tingkat signifikansi yang ditentukan, yaitu 0,05 $(0,048<0,05)$, dengan kata lain variabel kepemilikan institusional, kepemilikan manajerial, komite audit, komisaris independen, audit tenure, ukuran perusahaan dan leverage secara bersama-sama mempengaruhi terhadap integritas laporan keuangan secara signifikan.

Koefisien Determinasi. Berikut adalah tabel hasil uji koefisien determinasi:

Tabel 6

Uji KoefisienDeterminasi $\left(\mathbf{R}^{\mathbf{2}}\right)$

\begin{tabular}{|l|r|r|r|r|}
\hline Model & R & R Square & $\begin{array}{c}\text { Adjusted R } \\
\text { Square }\end{array}$ & $\begin{array}{c}\text { Std. Error } \\
\text { of the } \\
\text { Estimate }\end{array}$ \\
\hline I &, $565^{\mathrm{a}}$ &, 47 &, 45 &, 39020 \\
\hline
\end{tabular}

Sumber: Data sekunderyangdiolah

Pada table 6 menunjukan bahwa nilai koefisien Adjusted $R$ Square sebesar 0,45 hal ini berarti hanya $45 \%$ variable integritas laporan keuangan dapat dijelaskan oleh variable kepemilikan institusional, kepemilikan manajerial, komite audit, komisaris independen, audit tenure, ukuran perusahaan dan leverage sedangkan sisanya sebesar $55 \%$ dijelaskan oleh faktor-faktor lain yang tidak termasuk dalam analisis regresi ini, seperti independensiauditor, kualitas audit dan spesialisasi indutri auditor.

\section{Pembahasan}

Pengaruh Kepemilikan Institusional (INT) terhadap Integritas Laporan Keuangan.

Hasil uji parsial Kepemilikan

Institusional (INT) dalam penelitian ini menunjukan hasil bahwa INT tidak berpengaruh secara signifikan terhadap integritas laporan keuangan.Hal ini mengindikasikan bahwa pemegang saham institusional mempercayakan kepada manajerial untuk mengelola perusahaan. Hasil ini sejalan dengan penelitian Hardiningsih (20I0) menunjukan bahwa kepemilikan institusional tidak berpengaruh terhadap integritas laporan keuangan(Hardiningsih, 2010). Penelitian ini juga sejalan dengan Penilirian Saputra, Desmiati dan Anisma (20I4) menyatakan bahwa kepemilikan instutisional tidak ada kaitannya terhadap integritas laporan keuangan karena kepemilikan institusional pada umumnya akan lebih fokus kepada perolehan laba pada tahun berjalan dari pada proses penyusunan laporan keuangan(Saputra, et al., 20I4).

\section{Pengaruh Kepemilikan Manajerial (MAN) terhadap Integritas Laporan Keuangan.}

Hasil uji parsial Kepemilikan Manajerial (MAN) dalam penelitian ini menunjukan hasil bahwa MAN berpengaruh secara signifikan terhadap integritas laporan keuangan. Hal ini apabila tingginya kepemilikan manajerial $\mathrm{di}$ suatu perusahaan, maka tinggi pula saham yang dimiliki manajemen perusahaan itu. Kemungkinan besar perusahaan akan lebih meningkatkan auditing pada laporan keuangan perusahaan itu sendiri dan kemungkinan kecil terjadinya kecurangan laporan keuangan terjadi, maka dari itu integritas laporan keuangan akan lebih baik. Hasil penelitian ini konsisten dengan hasil penelitian Hardiningsih (20I0) yang menyebutkan bahwa kepemilikan manajerial berpengaruh terhadap integritas laporan keuangan (Hardiningsih, 20l0). Hal ini dapat dijelaskan dari teori agensi yang menggunakan tiga asumsi sifat manusia (Eisenhardt, 1989 dalam Hardinigsih,2010), yaitumanusia pada umumnya lebih mementingkan dirinya sendiri, manusia memiliki daya pikir terbatas mengenai persepsi masa akan datang dan manusia selalu menghindari resiko. Berdasarkan hasil 


\section{Jurnal Pendidikan Ekonomi}

tersebut menunjukan bahwa semakin besar kepemilikan saham yang dimiliki oleh manajemen ada kecenderungan untuk menjaga integritas laporan keuangannya.

\section{Pengaruh Komite Audit(KAUD) terhadap Integritas Laporan Keuangan.}

Hasil uji parsial dalam penelitian ini menunjukan hasil bahwa KAUD tidak berpengaruh terhadap integritas laporan keuangan, karena berdasarkan data yang diperoleh hasilnya menunjukan negatif. $\mathrm{Hal}$ ini terjadi dikarenakan bahwa komite audit hanya sebagai penunjang Dewan Komisaris untuk menerapkan good corporate governance dalam suatu perusahaan publik, bahkan Dewan Komisaris bisa sewaktu-waktu memberhentikan komite audit. Adanya pengaruh ini menyebabkan komite audit kurang memaksimalkan perannya di perusahaan. Hasil penelitian ini sejalan dengan penelitian sebelumnya yaitu penelitian Wulandari dan Budiartha (20I4), yang menunjukan bahwa komite audit tidak berpengaruh terhadap integritas laporan keuangan (Wulandari et al., 20I4). Penelitian ini juga sejalan dengan penelitian Nurjanah dan Pratomo. (2014) yang menunjukan bahwa komite audit tidak berpengaruh signifikan terhadap integritas laporan keuangan (Nurjanah et al., 2014) Parah koefisien yang negative menunjukan bahwa keberadaan komite audit hanya sebatas pemenuhan regulasi, tetapi tidak disertai dengan kinerja yang efektif. Selain itu, ada kecenderungan komite audit belum mampu menunjukan kedudukannya yang berdiri sendiri, ini menandakan masih besarnya pengaruh kekuasaan eksekutif daripada komite auditnya.

\section{Pengaruh Komisaris Independen (KIND) terhadap Integritas Laporan} Keuangan.

Hasil uji parsial Komisaris Independen (KIND) dalam penelitian ini menunjukan hasil bahwa KIND tidak berpengaruh terhadap integritas laporan keuangan. $\mathrm{Hal}$ ini mengindikasikan komisaris independen yang kurang memaksimalkan perannya dan juga banyak perusahaan yang kurang memperhatikan komposisi dewan komisaris, selain itu pengetahuan dan latar belakang komisaris independen harus sesuai dengan bisnis perusahaan. Hasil penelitian ini sejalan dengan hasil penelitian bahwa komisaris independen tidak berpengaruh. Hasil pengujian ini juga sejalan dengan hasil penelitian dari Nurjanah dan Pratomo (20l4) yang menyatakan bahwa komisaris independen tidak berpengaruh signifikan terhadap integritas laporan keuangan (Nurjanah et al., 20I4). Penelitian ini juga sejalan dengan penelitian Wulandari dan Budhiartha (2014) yang menunjukan komisaris independen tidak memili pengaruh terhadap integritas laporan keuangan (Wulandari,et al., 20l4). Hal ini disebabkan masih cukup banyaknya perusahaan yang belum membentuk komisaris independen atau jumlah komisaris independen dalam perusahaan kurang dari $25 \%$, sehingga menyebabkan kurang efektifnya dalam menjalankan pengawasan terhadap proses penyusunan laporan keuangan.

\section{Pengaruh Audit Tenure (ATEN) terhadap Integritas Laporan Keuangan.}

Hasil uji parsial Audit Tenure (ATEN) dalam penelitian ini menunjukan hasil bahwa ATEN berpengaruh terhadap integritas laporan keuangan. Hal ini semakin panjang masa perikatan audit maka akan menambah integritas laporan keuangan, karena auditor telah paham mengenai perusahaannya sehingga auditor dapat bekerja lebih efektif danefisien. Hasil penelitian ini konsisten dengan hasil penelitian Giri (2010)yang menunjukan bahwa tenur KAP yang lama akan menaikan kualitas audit (Giri, 20I0). Beberapa alas an yang mendasari hasil ini adalah tenur KAP yang panjang akan menciptakan pengetahuan yang 


\section{Jurnal Pendidikan Ekonomi}

cukup bagi auditor/KAP untuk melaksanakan tugas audit secaraprofesional, tenur auditor yang panjang justru akan menghasilkan kos yang lebih renda hdan pengetahuan yang cukup dimiliki oleh auditor/KAP akan membuat auditor semakin teliti.

Pengaruh Ukuran Perusahaan (SIZE) terhadap Integritas Laporan Keuangan.

Hasil uji parsial Ukuran Perusahaan (SIZE) dalam penelitian ini menunjukan hasil bahwa SIZE berpengaruh terhadap integritas laporan keuangan. Hal ini mengindikasikan bahwa semakin besar perusahaan maka akan semakin memperhatikan laporan keuangannya, karena perusahaan besar mempunyai banyak pemangku kepentingan. Hasil penelitian ini sejalan dengan penelitian Fajaryani (2015) yang menyatakan bahwa ukuran perusahaan berpengaruh signifikan terhadap integritas laporan keuangan(Fajaryani, 20I5). Ukuran perusahaan dianggap memiliki peranan penting dalam penyajian laporankeuangan. Perusahaanbesar akan menghadapi tuntutan yang lebih besar dari para pemegang saham untuk menyajikan laporan keuangan yang berintegritas tinggi. Penelitian Saputra, Desmiawati ,dan Anisma (2014) menunjukan hasil yang sama bahwa ukuran perusahaan berpengaruh positif secara signifikan terhadap integritas laporan keuangan (Saputra, et al., 2014). Hal ini menunjukan bahwa semakin meningkat ukuran perusahaan maka akan semakin meningkat integritas laporan keuangannya, sebaliknya apabila ukuran perusahaan menurun maka integritas laporan keuangan perusahaan tersebut juga akan mengalami penurunan.

\section{Pengaruh Leverage terhadap Integritas Laporan Keuangan.}

Hasil uji parsial Leverage dalam penelitian ini menunjukan hasil bahwa berpengaruh terhadap integritas laporan
keuangan.Hal ini mengindikasikan bahwa perlunya integritas laporan keuangan yang tinggi untuk memperoleh pinjaman dari pihak lain (kreditur). Keberadaan tingkat utang dalam struktur pendanaan perusahaan akan meningkatkan pengawasan tidak hanya oleh investor namun juga kreditur. $\mathrm{Hal}$ ini mengindikasikan bank dan pemberi pinjaman lainnya akan semakin bergantung terhadap laporan keuangan perusahaan, karena sulitnya mendapatkan jaminan atas personal guarantees dan kolateral dari pemilik perusahaan yang semakin besar. Penelitian ini sejalan dengan penelitian Fajaryani (20I5) bahwa leverage berpengaruh signifikan terhadap integritas laporan keuangan(Fajaryani, 20I5).

\section{KESIMPULAN}

Berdasarkan hasil analisa dan pembahasan yang telah dilakukan terhadap permasalahan dengan melakukan analisa regresi berganda, diperoleh kesimpulan bahwa Kepemilikan institusional, kepemilikan manajerial, komite audit, komisaris independen, audit tenure, ukuran perusahaan dan leverage secara bersama-sama (simultan) berpengaruh terhahadap integritas laporan keuangan. Secara parsial Kepemilikan Manajerial, Audit Tenure, Ukuran Perusahaan, Leverage berpengaruh positif terhadap integritas laporan keuangan. Sedangkan Kepemilikan Institusional, Komite Audit, Komisaris Independen tidak berpengaruh terhadap integritas laporan keuangan.

Bagi penelitian selanjutnya dapat menambah variabel seperti faktor-faktor lainyang tidak termasuk dalam analisis regresi ini, seperti independensiauditor, kualitas audit dan spesialisasiindutri auditor.

\section{DAFTAR PUSTAKA}

Amperaningrum, I. and Sari, I. K. 2013. Pengaruh Good Corporate Governance, Leverage, Dan Kinerja Keuangan Terhadap Manajemen Laba 
Jurnal Pendidikan Ekonomi

Studi, Jurnal Proceeding PESAT (Psikologi, Ekonomi, Sastra, Arsitektur \& Teknik Sipil), 5(I), pp. 8-9.

Asyati, S. and Farida, F. 2020. Pengaruh Good Corporate Governance, Leverage, Profitabilitas dan Kualitas Audit terhadap Praktik Manajemen Laba (Studi Empiris pada Perusahaan Manufaktur yang Terdaftar di BEI Periode 20/4-2018), Journal of Economic, Management, Accounting and Technology, 3(I), pp. 36-48. doi: I0.32500/jematech.v3il.I073.

Budiasih, I. G. A. N. and Saputri, P. D. A. 2017. Corporate Governance Dan Financial Distress Pada Kecepatan Publikasi Laporan Keuangan, Kinerja, I8(2), P. I57. doi: I0.24002/kinerja.v I 8i2.527.

Dewi, D. and Budiartha, I. 2015 'Pengaruh Kompetensi Dan Independensi Auditor Pada Kualitas Audit Dimoderasi Oleh Tekanan Klien', E-Jurnal Akuntansi, II(I), PP. 197-2I0.

Diplan. Peningkatan Kemampuan Membaca Pemahaman dengan Strategi Pemecahan Masalah Siswa Kelas V SDN 5 Panarung Palangka Raya.(Tesis). DISERTASI dan TESIS Program Pascasarjana UM, 2009.

Fajaryani, A. 2015. Analisis Faktor-Faktor Yang Mempengaruhi Integritas Laporan Keuangan (Studi Empiris pada Perusahaan Pertambangan yang Terdaftar di Bursa Efek Indonesia Periode 2008-2013), Jurnal Nominal, 4(2005), Pp. 10-17. doi: I0.1 I45/3 I32847.3I 32886 .

Fakhruddin. 2015. Pasar Modal di Indonesia. Jakarta: Salemba Empat.

Giri, E. F. 2010. Pengaruh Tenur Kantor Akuntan Publik (Kap) Dan Reputasi Kap Terhadap Kualitas Audit $\square$ : Kasus Rotasi Wajib Auditor Di Indonesia'.

Hardiningsih, P. 20I0. Pengaruh Independensi, Corporate Governance, Dan Kualitas Audit Terhadap Integritas Laporan Keuangan, Kajian Akuntansi, 2(I), PP. 6I-76. doi: I0.IIII/I2.262835.

Herianti, E. and Suryani, A. 2016. Pengaruh Kualitas Auditor, Audit Delay Dan Audit Tenure Terhadap Kualitas Audit Perbankan Yang Terdaftar, Prosiding
Seminar Nasional INDOCOMPAC, PP. 416-425.

IAI. 20I5. Standar Akuntansi Keuangan- IAI Global. Available at: http://www.iaiglobal.or.id/v03/standarakuntansi-keuangan/sak (Accessed: 21 April 2020).

Indrasari, A., Yuliandhari, W. S. and Triyanto, D. N. 2016. Pengaruh komisaris independen, komite audit, dan financial distress terhadap integritas laporan keuangan, Jurnal Akuntansi, 20(I), P. II 7.

Jailani, Muhammad. 2019. Hubungan Status Sosial Ekonomi Orang Tua Terhadap Motivasi Anak Untuk Berwirausaha. Pedagogik: Jurnal Pendidikan, I4(I):3542.

Karyanti, Muhammad Andi Setiawan. 2018. Model Konseling Kelompok Teknik Expresif Writing Berlandaskan Falsafah Dandang Tingang Untuk Meningkatkan Perilaku Respect. JURKAM: Jurnal Konseling Andi Matappa, 2(2): 129-I36.

Keputusan Menteri Keuangan Nomor. I7/PMK.0I/2008 tentang Jasa AkuntanPublik.

Kholmi, M. 20I0. Akuntabilitas dalam Perspektif Teori Agensi', Ekonomika Bisnis, 02(02), p. hal. 357-370.

Kusumawatil, E., Trisnawati, R. and Mardalis, A. 2015. Pengaruh Good Covernance Terhadap Manajemen Laba, The 2nd University Research Coloquium 2015, Pp. 339-350.

Mulyadi. 2002. Auditing Buku 2. 6th edn. Jakarta Selatan: Salemba 4.

Nurjanah, L. and Pratomo, D. 20I4. Pengaruh Komite Audit, Komisaris Independen Dan Kualitas Audit Terhadap Integritas Laporan Keuangan ( Pada Perusahaan Manufaktur Yang Terdaftar Di Bursa Efek Indonesia Tahun 2012), Jurnal Bisnis dan Manajemen, I(3), PP. 99105. Available at: https://id.scribd.com/document/268343 040.

Praptika, P. and Rasmini, N. 2016. Pengaruh Audit Tenure, Pergantian Auditor Dan Financial Distress Pada Audit Delay Pada Perusahaan Consumer Goods, EJurnal Akuntansi, I5(3), pp. 2052-208I. 
Jurnal Pendidikan Ekonomi

Ramli, Muhamad \& Isnawati. 2016. Upaya Meningkatkan Hasil Belajar IPS dengan Menggunakan Model Pembelajaran Course Review Horay. Bitnet: Jurnal Pendidikan Teknologi Informasi, I(I):610.

Riadin, Agung, dkk. 2017. Karakteristik Anak Berkebutuhan Khusus di Sekolah Dasar Negeri (Inklusi) di Kota Palangka Raya. Anterior Jurnal, I7(I):22-27.

Rifai, M., Arifati, R. and Magdalena, M. 2015. Pengaruh Ukuran Perusahaan, Struktur Modal Dan Pertumbuhan Perusahaan Terhadap Profitabilitas Studi Pada Perusahaan Manufaktur Di Bei Tahun 20I0-20I2, Jurnal Ilmiah Mahasiswa SI Akuntansi Universitas Pandanaran, I (2502-7697), pp. I-8.

Saputra, W., Desmiawati and Anisma, Y. 2014. Pengaruh Mekanisme Good Corporate Governance, Dan Ukuran Perusahaan Terhadap Integritas Laporan Keuangan (Studi Kasus pada Perusahaan Manufaktur Yang Terdaftar Di Bursa Efek Indonesia Periode 2012), I(2), pp. I-I5.

Savero, D., Nasir, A. and Safitri, D. 2017. Pengaruh Komisaris Independen, Komite Audit, Kepemilikan Instutisional dan Kepemilikan Manajerial terhadap Integritas Laporan Keuangan (Studi Empiris pada Perusahaan Manufaktur yang Terdaftar di Bursa Efek Indonesia Tahun 20I2-20I4), Jurnal Online Mahasiswa Fakultas Ekonomi Universitas Riau, 4(I), pp. 75-89.

Setiawan, K. N. 2016. Pengaruh Mekanisme Corporate Governance, Audit Tenure, Dan Ukuran Perusahaan Terhadap I 437 H / 2016 M Pengaruh Mekanisme Corporate Governance, Audit Tenure Dan Ukuran Perusahaan Terhadap.

Solikhah, N. and Hamid, M. 2017. Pengaruh Independensi, Mekanisme Corporate Governance Dan Kualitas Audit Terhadap Integritas Laporan Keuangan (Studi Empiris', Akuntansi, 5(2), PP. 167-I78. Available at: https://I03.247.10.25I/index.php/akunt ansi/article/view/363 (Accessed: 21 April 2020).

Suwito, E. and Herawaty, A. (2005) 'Industrial type, size of the company, company's profitability ratios, company's operating leverage ratios, company's net profit margin, income smoothing.', SNA VII Solo.

Wulandari, N. and Budiartha, I. 2014. Pengaruh Struktur Kepemilikan, Komite Audit, Komisaris Independen Dan Dewan Direksi Terhadap Integritas Laporan Keuangan, E-Jurnal Akuntansi, 7(3), PP. 574586. 